\title{
Applications and Future Development of Sewage Source Heat Pump
}

\author{
Yu YU \\ School of Thermal Engineering \\ Shandong Jianzhu University \\ Jinan, China \\ e-mail: Leona_YY@163com,
}

\author{
Hui LI \\ School of Thermal Engineering \\ Shandong Jianzhu University \\ Jinan, China \\ e-mail:1hh@sdjzu.edu.cn
}

\author{
Lin WANG \\ School of Thermal Engineering \\ Shandong Jianzhu University \\ Jinan, China
}

\begin{abstract}
The sewage source with widely distributed is a kind of low grade energy. The sewage source heat pump technology can achieve the energy conversion that the sewage source from low grade energy to high grade energy of sewage. The system sewage source heat pump supplies heat energy and cold energy to meet the users' thermal comfort requirements,as well as supplies domestic hot water. This paper introduces the new technology of sewage source heat pump. Its economic benefits and environmental benefits are analyzed with a specific project. The results prove that the sewage source heat pump has good environmental benefits and economic benefits. Its has a broad development prospects in future.
\end{abstract}

Keywords-sewage; sewage source heat pump; economy; environmental protection

\section{INTRODUCTION}

In recent years, with the development of economy and the improvement of people's living standard, the problem of energy shortage and environmental pollution has become a hot issue for the whole world. The sewage source heat pump system uses urban sewage as its cold and heat source and extracts energy from the sewage by consuming a small amount of power, then the refrigerant state in the heat pump system will be changed, finally the system achieves the purpose of cooling and heating[1]. The sewage source heat pump system has good environmental benefits and economic benefits, so the system receives widespread attention around the word.

\section{Sewage-Source Heat Pump And Its CHARACTERISTICS}

With the improvement of life quality, people put forward a higher requirement that the comfort of living environments. The region where needs heating in winter and cooling in summer is becoming more and more widely, and then the building energy consumption becomes higher and higher. So the topic of develop economic and clean energy has attracted many scholars' attention. The traditional air conditioning chiller and boiler require their own equipment, including a host device and a set of terminal device system. However, the sewage source heat pump system can realize three functions: winter heating, summer cooling, and hot water supply[2].

In winter, the sewage temperature is about $10^{\circ} \mathrm{C} \sim 16^{\circ} \mathrm{C}$, which is higher than the outdoor temperature. In summer sewage temperature is about $22^{\circ} \mathrm{C} \sim 25^{\circ} \mathrm{C}$, which is lower than the outdoor temperature[3]. So comparing with traditional air conditioning system, the sewage-source heat pump has a higher coefficient of cooling and heating. At the same time, the sewage source heat pump system uses urban sewage as its cold and heat source, and only consume a small amount of electricity, it can achieve aim of supplying heating and cooling. Therefore, the development of sewage source heat pump system can effectively reduce the use of non-renewable energy such as coal and oil.

\section{The PRINCIPLE AND THE ClasSification OF Sewage-Source Heat Pump System}

\section{A. The Principle Sewage-Source Heat Pump System}

Figure 1 is a schematic diagram of the sewage source heat pump system's heating cycle. The sewage source heat pump's heating system uses a simple vapor compression heat pump device as its heat sources. The device is mainly composed of an evaporator, a throttling device, a compressor and a condenser. The system obtains heat $\mathrm{Q}_{\mathrm{w}}$ from waste water by using an evaporator ,then through the condenser release heat $\mathrm{Q}_{\mathrm{l}}=\mathrm{Q}_{\mathrm{w}}+\mathrm{W}(\mathrm{W}$ is the electric energy consumption of the heating system). 


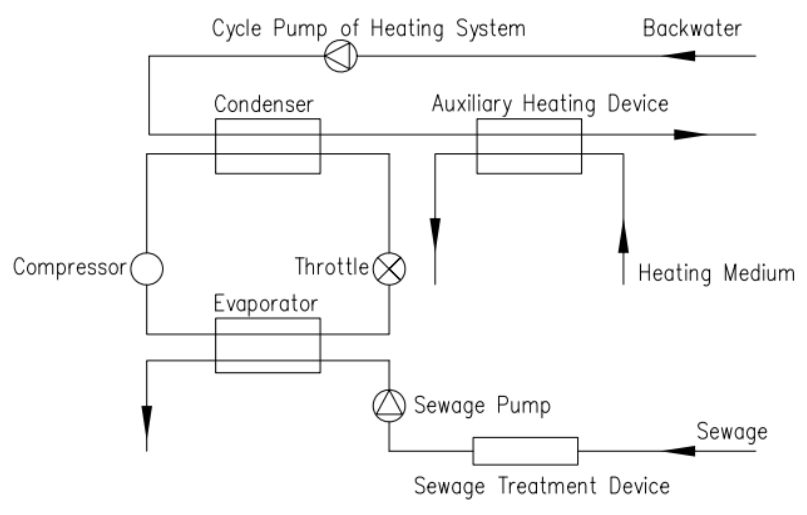

Figure 1. The heating schematic diagram of sewage source heat pump.

\section{B. Classification of Sewage Source Heat Pump System}

(1) According to the sewage treatment status, sewage source heat pump system can be divided into two types: One uses untreated waste water, the other one uses secondary effluent water or middle water.The first system's characteristics includes: (a)The energy directly comes from the urban drainage, so it is convenient to obtain energy. (b)The composition of sewage is very complex, so the system is easily clogged by dirt substance[4].The second system's characteristics including: (a)The quality of sewage water is better and the quantity of water is stable. (b)There are heat losses during transmission, so the distance between the sewage treatment plant and the user should not be too far.
(2) According to the sewage whether flow into the heat pump unit, the system can be divided into direction and indirection.In the direct sewage source heat pump system, most systems' cold and heat sources are treated water, the heating transfer between the sewage and the heat pump is direct.In the indirect sewage-source heat pump system, most systems' cold and heat source are untreated water, heat will be exchanged between the sewage and the heat exchanger which is in the front of the heat pump system. Then the heat exchanger releases heat to the heat pump system.

At present, the technology of indirect sewage-source heat pump systems gets mature, and many buildings take this system. But in the direct sewage source heat pump system, there is no middle heat exchanger between the sewage treatment and the heat pump system. So the efficiency of energy conversion is much higher, and the system has obvious energy conservation and environment protection benefit[5].Generally speaking, the indirect sewage source heat pump system is the main development tendency in future.

\section{ECONOMic Analysis of Waste Water Resource HEAT PUMP}

This is an air conditioning system of office building in Jinan. Because the user side system of the sewage source heat pump air conditioning system and the conventional air conditioning system is same, so only comparing the initial investment of the engine room.

TABLE I. THE INITIAL INVESTMENT OFTHE ENGINE ROOM

\begin{tabular}{|c|c|c|c|c|c|}
\hline & Device Name & Modle & Quantity & Unit Price & $\begin{array}{c}\text { Total Price (Thousand } \\
\text { Yuan) }\end{array}$ \\
\hline \multirow{9}{*}{$\begin{array}{c}\text { Sewage- } \\
\text { Source } \\
\text { Heat } \\
\text { Pump }\end{array}$} & Water-Source Heat Pump Unit & RHSBW140HM & 3 Set & 180 & 540 \\
\hline & Cold/Hot Water Circulating Pump & CR64-1 & 2 Set & 3 & 6 \\
\hline & Water Pump & SP46-4 & 2 Set & 5 & 10 \\
\hline & Supplementary Water Pump & & 2 Set & 2 & 4 \\
\hline & Automatic Cleaning Strainer & ZG100-L & 1 Set & 36 & 36 \\
\hline & Accessory Equipment & & 1 Set & 63.68 & 63.68 \\
\hline & Material & & & & 79.8 \\
\hline & Installation Cost & & & & 69 \\
\hline & Summation & & & & 808.48 \\
\hline \multirow{10}{*}{$\begin{array}{c}\text { Cold } \\
\text { Water } \\
\text { Chiller+ } \\
\text { Boiler } \\
\text { System }\end{array}$} & Oil-Burning Boilers & DSJ30 & 1 Set & 85 & 85 \\
\hline & Water Chiller & KLSW-040S & 3 Set & 160 & 480 \\
\hline & Cold Water Pump & CR64-1 & 2 Set & 3.1 & 6.2 \\
\hline & Cooling Water Pump & SP46-4 & 2 Set & 3.1 & 6.2 \\
\hline & Supplementary Water Pump & & 2 Set & 2 & 4 \\
\hline & Cooling Tower & LBCM-50 & 1 Set & 50 & 50 \\
\hline & Accessory Equipment & & 1 Set & 63.68 & 63.68 \\
\hline & Material & & & 85 & 85 \\
\hline & Installation Cost & & & 75 & 75 \\
\hline & Summation & & & & 855.08 \\
\hline
\end{tabular}


From Table I shows, the initial investment of using sewage-source heat pump air conditioning system about $10 \%$ lower than using electric refrigeration chiller and oil-fired boiler.

In Jinan,the cooling period is about 90 days, air conditioning running about $10 \mathrm{~h}$ per day. The heating period is about 120 days, air conditioning running about $20 \mathrm{~h}$ per day.(Electricity: 0.4yuan/kWh; Diesel: 4.2yuan/kg)

TABLE II. THE AIR CONDITIONING ENERGY CONSUMPTION AND OPERATION COST

\begin{tabular}{|c|c|c|c|}
\hline & \multirow[t]{2}{*}{ Device Name } & \multicolumn{2}{|c|}{$\begin{array}{l}\text { Air conditioning system energy } \\
\text { consumption/(KW) }\end{array}$} \\
\hline & & Summer & Winter \\
\hline \multirow{7}{*}{$\begin{array}{c}\text { Sewage- } \\
\text { Source } \\
\text { Heat } \\
\text { Pump }\end{array}$} & $\begin{array}{c}\text { Water-Source Heat } \\
\text { Pump Unit }\end{array}$ & $30.1 \times 2$ & $39.7 \times 2$ \\
\hline & $\begin{array}{l}\text { Cold/Hot Water } \\
\text { Circulating Pump }\end{array}$ & $7.5 \times 1$ & $7.5 \times 1$ \\
\hline & Water Pump & $5.5 \times 1$ & $5.5 \times 1$ \\
\hline & $\begin{array}{c}\text { Supplementary } \\
\text { Water Pump }\end{array}$ & $2.0 \times 2$ & $2.0 \times 2$ \\
\hline & $\begin{array}{c}\text { Automatic Cleaning } \\
\text { Strainer }\end{array}$ & $1.5 \times 1$ & $1.5 \times 1$ \\
\hline & $\begin{array}{l}\text { Accessory } \\
\text { Equipment }\end{array}$ & $0.1 \times 1$ & $0.1 \times 1$ \\
\hline & Summation & 78.8 & 98 \\
\hline \multirow{7}{*}{$\begin{array}{c}\text { Cold } \\
\text { Water } \\
\text { Chiller+ } \\
\text { Boiler } \\
\text { System }\end{array}$} & Oil-Burning Boilers & & \multirow{2}{*}{$\begin{array}{l}0.75 \times 1(\text { Diesel } \\
32.7 \mathrm{~kg} / \mathrm{h})\end{array}$} \\
\hline & Water Chiller & $30.0 \times 2$ & \\
\hline & Cold Water Pump & $7.5 \times 1$ & $7.5 \times 1$ \\
\hline & Cooling Water Pump & $7.5 \times 1$ & $7.5 \times 1$ \\
\hline & $\begin{array}{l}\text { Supplementary } \\
\text { Water Pump }\end{array}$ & $2.0 \times 2$ & $2.0 \times 2$ \\
\hline & $\begin{array}{l}\text { Accessory } \\
\text { Equipment }\end{array}$ & $0.1 \times 1$ & $0.1 \times 1$ \\
\hline & Summation & 79.1 & $\begin{array}{l}19.85(\text { Diesel } \\
32.7 \mathrm{~kg} / \mathrm{h})\end{array}$ \\
\hline
\end{tabular}

From table II shows, two system roughly have the same summer operating cost. In winter, the operating cost of using sewage-source heat pump air conditioning system about $68 \%$ lower than using electric refrigeration chiller and oil-fired boiler. And for the full year,sewage-source heat pump air conditioning system save about $60 \%$ of energy.

\section{ENVIRONMENTAL BENEFIT ANALYSIS OF WASTE WATER Resource HeAT PUMP}

With the continuous development of economy, mankind is faced with many serious environmental problems. The operation of air-conditioner system has a significant impact on the environment. First refrigerant leakage will cause serious pollution on the water and natural environment, and the operation of sewage source heat pump needs a large amount of energy. Then in the process of energy consumption, the burning of the fuel will produce lots of pollutant and cause serious pollution to the environment. For example, because excessive use refrigerant, the ecological environment has been seriously damaged. The pollutants include particulate emissions (TPS), sulfur dioxide $\left(\mathrm{SO}_{2}\right)$, nitrogen oxides $\left(\mathrm{NO}_{\mathrm{x}}\right.$, ) carbon dioxide $\left(\mathrm{CO}_{2}\right)$. $\mathrm{SO}_{2}$ and $\mathrm{NO}_{\mathrm{x}}$ can form acid rain and secondary pollutants. And carbon dioxide emissions can cause global warming, then it will cause glacier melt, sea-level rising and frequent natural disasters.

According to references, comparing with traditional air conditioning system, sewage-source heat pump central air conditioning system cut $\mathrm{CO}_{2}$ emissions by $40 \% \sim 51 \%, \mathrm{NO}_{\mathrm{x}}$ emissions by 36\% 49\%; sewage-source heat pump distributed air conditioning system cut $\mathrm{CO}_{2}$ emissions by $13 \%, \mathrm{NO}_{\mathrm{x}}$ emissions by $13 \%$.

Sewage source heat pump system only consumes a small amount of electrical energy in the operation process, and doesn't produce waste residue, sewage and waste gas. So sewage source heat pump system have significant environmental benefits.

\section{CONCLUSION}

Global energy crisis and environmental pollution are becoming increasingly serious. Energy in sewage is a kind of clean energy[6], which has not been effectively developed and utilized. So it is an effective way to change the coal-dominated energy consumption structure of large cities by promoting the use of sewage source heat pump systems. Sewage source heat pump technology is becoming more and more mature, so it provides a reliable technical guarantee for the popularization and application of urban sewage heat energy. The sewage source heat pump technology develops a new space for sewage treatment, and it's an important research content for development renewable energy sources. Therefore,the development of sewage source heat pump has long-term strategic significance.

\section{REFERENCES}

[1] T.Yoshii. Technology for Utilizing Unused Low Temperature Difference Energy.Journal of Japan Institute of Energy. 2001,(8):696-706.

[2] Arashi Norio. Evaluation of energy use in district heating and cooling plant using sewage and one using air as heat source. Joural of the Japan Institute of Energy,2000 (5):446-454.

[3] Thore Berntsson. Heat Sources-Technology, Tconomy and Environment, International Journal of Refrigeration. 2002,(25):428-438.

[4] CADDET.Reduced fouling of sewage water heat pumps. Demo 33,JP 93.501 /5X H03, 1995.

[5] J.R.Lines. Heat Exchangers in Municipal Wastewater Treatment Plants, Water/Engineering and Management. 1991, (9):28-29.

[6] Satoru Okamoto. A heat pump system with a latent heat storage utilizing seawater installed in an aquarium. Energy and Buildings 2004, 11: $121-128$. 